\title{
Heat utilization and productivity of summer transplanted rice (Oryzasativa L.) in relation to irrigation schedules and date of transplanting
}

\author{
B.R. NAYAK ${ }^{1^{*}}$, N. PANIGRAHY ${ }^{1}$, S. MOHAPATRA ${ }^{1}$, A.K. MOHANTY ${ }^{1}$, \\ B. SAHOO ${ }^{2}$, P.N. JAGDEV ${ }^{3}$ and S. PATEL ${ }^{3}$ \\ ${ }^{1}$ Regional Research and Technology Transfer Station, OUAT, Chiplima,Odisha \\ ${ }^{2}$ KrishiVigyan Kendra, OUAT, Ranital, Bhadrak, Odisha \\ ${ }^{3}$ Orissa University of Agriculture and Technology (OUAT), Bhubaneswar, Odisha \\ *Corresponding author Email:biswa.nayak@yahoo.co.in
}

\begin{abstract}
A study was undertaken at Regional Research and Technology Transfer Station, Chiplima, Sambalpur, Odisha on rice var. khandagiri during summer season of 2011, 2012 and 2013 in split plot design with three irrigation schedule (main plots) and three date of transplanting (sub plots). Experimental results indicated that the irrigation schedules at one day after disappearance of ponded water (DPW) recorded the highest grain yield of $3.07 \mathrm{t} \mathrm{ha}^{-1}$ which was at par with irrigation schedule at 2-days after DPW. Both the irrigation schedules were significantly superior over 3-days after DPW. The date of transplanting on $15^{\text {th }}$ January produced highest grain yield $\left(3.11 \mathrm{t} \mathrm{ha}^{-1}\right)$ which was significantly superior to other transplanting date on $30^{\text {th }}$ January and $15^{\text {th }}$ February. Highest water use efficiency was observed

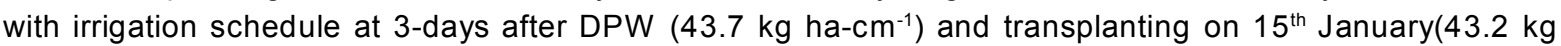
ha- $\left.\mathrm{cm}^{-1}\right)$. The treatment that received irrigation schedule at 1-day after DPW registered the highest dry matter heat use efficiency $\left(3.62 \mathrm{~kg} \mathrm{ha}^{-10} \mathrm{C}\right.$ day $\left.^{-1}\right)$ and grain yield heat use efficiency $\left(1.84 \mathrm{~kg} \mathrm{ha}^{-10} \mathrm{C}\right.$ day $\left.^{-1}\right)$. The transplanting on $15^{\text {th }}$ January produced highest dry matter heat use efficiency $\left(3.83 \mathrm{~kg} \mathrm{ha}^{-10} \mathrm{C}\right.$ day $\left.^{-1}\right)$ and grain yield heat use efficiency $\left(2.05 \mathrm{~kg} \mathrm{ha}^{-10} \mathrm{C}\right.$ day $\left.{ }^{-1}\right)$ which was significantly superior to other transplanting dates of $30^{\text {th }}$ January and $15^{\text {th }}$ February.
\end{abstract}

Key words: Heat use efficiency, productivity, summer rice,transplanting dates, water use efficiency

Rice (Oryza sativa L.) plays an important role in providing food to two third of the world population particularly in Asian countries. Hence, rice is known as Asia's lifeline. In India, demand for rice is growing every year and it is estimated that by $2025 \mathrm{AD}$ the requirement would be 140 million tonnes. To sustain present food self-sufficiency and to meet future food requirements, India has to increase its rice productivity by three per cent per annum (Thiyagarajan and Selvaraju, 2001).Date of transplanting is a vital factor that affects grain yield of summerrice considerably. Summer rice is transplanted in winter facing high temperature in summer at its reproductive stages. Optimum time of planting proved to give better yield response by offering prolonged growth period while eliminating chances of heat stress during reproductive growth (Hassan et al. 2003). Heat use efficiency (HUE) i.e efficiency of utilization of heat in terms of dry matter accumulation or economic yield of rice depends on solar radiation interception, leaf area development and crop management practices (Aggarwal et al.2015).

Irrigation plays a vital role in increasing the productivity of rice though the efficiency and productivity of water are very low due to percolation losses and higher water requirement. The increasing the cost of irrigation water and associated with decline in return are encouraging producers to use water more efficiently. It is therefore essential to find out proper irrigation schedule especially during dry season to maintain proper growth and yield of rice. Keeping the above facts in to consideration, the present investigation was planned to find out proper transplanting date and irrigation schedule for rice cultivation during summer season.

\section{MATERIALS AND METHODS}

An experiment was conducted to evaluate the heat stress management through adjustment of transplanting date and irrigation water management during 2011, 2012 and 2013 at the Regional Research Technology and Transfer Station, Chiplima, Sambalpur, Odisha. The acidic $(\mathrm{pH}, 6.2)$ soil of the experimental field was sandy loam in texture, low in organic carbon $(0.41 \%)$ and available $\mathrm{N}, \mathrm{P}$ and $\mathrm{K}$ content were $244,12.0$ and $182 \mathrm{kgha}^{-1}$, respectively. The moisture 
Table 1: Growth and yield of summer transplanted rice as influenced by irrigation schedules and date of transplanting (pooled data of 3 years -2011 to 2013 )

\begin{tabular}{|c|c|c|c|c|c|c|c|c|}
\hline Treatments & $\begin{array}{l}\text { Plant height } \\
\text { at harvest } \\
(\mathrm{cm})\end{array}$ & $\begin{array}{l}\text { Dry matter } \\
\text { accumulation } \\
\text { at harvest } \\
\left(\mathrm{gm}^{-2}\right)\end{array}$ & $\begin{array}{c}\text { Leafarea } \\
\text { index at } \\
50 \% \\
\text { flowering }\end{array}$ & $\begin{array}{l}\text { Days taken } \\
\text { to } 50 \% \\
\text { flowering }\end{array}$ & $\begin{array}{l}\text { Effective } \\
\text { panicles } \\
/ \mathrm{m}^{2}(\text { nos })\end{array}$ & $\begin{array}{c}\text { Filled } \\
\text { grains/ } \\
\text { panicle } \\
\text { (nos) }\end{array}$ & $\begin{array}{c}\text { Test } \\
\text { weight } \\
(\mathrm{g})\end{array}$ & $\begin{array}{c}\text { Grain } \\
\text { yield } \\
\left(\mathrm{t} \mathrm{ha}^{-1}\right)\end{array}$ \\
\hline \multicolumn{9}{|c|}{ Irrigation schedule } \\
\hline 1 day after DPW & 76.3 & 600.7 & 3.81 & 73.6 & 252.3 & 73.6 & 22.5 & 3.07 \\
\hline 2 days after DPW & 75.5 & 553.8 & 3.67 & 75.4 & 243.4 & 71.1 & 22.0 & 2.96 \\
\hline 3days after DPW & 71.7 & 463.9 & 3.41 & 77.0 & 229.3 & 66.4 & 20.9 & 2.69 \\
\hline $\mathrm{SEm} \pm$ & 2.0 & 14.4 & 0.09 & 0.9 & 5.7 & 2.1 & 0.3 & 0.07 \\
\hline $\mathrm{CD}(\mathrm{P}=0.05)$ & NS & 50.0 & 0.30 & NS & NS & NS & 1.2 & 0.23 \\
\hline \multicolumn{9}{|l|}{ Transplanting date } \\
\hline $15^{\text {th }}$ January & 81.6 & 573.2 & 4.06 & 79.6 & 255.8 & 76.0 & 22.2 & 3.11 \\
\hline $30^{\text {th }}$ January & 75.2 & 552.0 & 3.58 & 76.4 & 245.1 & 72.1 & 21.9 & 2.97 \\
\hline $15^{\text {th }}$ February & 66.7 & 487.0 & 3.28 & 70.0 & 224.0 & 63.0 & 21.2 & 2.64 \\
\hline $\mathrm{SEm} \pm$ & 1.9 & 12.5 & 0.08 & 0.95 & 4.13 & 2.24 & 0.40 & 0.06 \\
\hline $\mathrm{CD}(\mathrm{P}=0.05)$ & 5.7 & 37.1 & 0.24 & 2.83 & 12.26 & 6.66 & $\mathrm{NS}$ & 0.18 \\
\hline
\end{tabular}

content at field capacity and permanent wilting point was 19.1 and 8.9 per cent, respectively. The total rainfall during the crop growth period was $7.2 \mathrm{~mm}, 27.8 \mathrm{~mm}$ and $65.5 \mathrm{~mm}$ during 2011, 2012 and 2013, respectively. The experiment was laid out in split plot design with 4 replications. Main plot treatments consist of three irrigation scheduling (1-day after DPW (disappearance of ponding water), 2-days after DPW, 3-days after DPW) with $50 \mathrm{~mm}$ of standing water in each irrigation and three date of transplanting $\left(15^{\text {th }}\right.$ January, $30^{\text {th }}$ January, $15^{\text {th }}$ February) in the sub-plots.Rice variety Khandagiri (100days duration) was taken as test crop with recommended dose of $\mathrm{N}, \mathrm{P}_{2} \mathrm{O}_{5}$ and $\mathrm{K}_{2} \mathrm{O}(80,40$ and $40 \mathrm{~kg}$ ha-1). Farm yard manure @ $5 \mathrm{tha}^{-1}$ was applied uniformly to all the plots irrespective of the treatments. The crop was transplanted with a spacing of $20 \mathrm{~cm} \times 10 \mathrm{~cm}$. All the other cultural operations were carried out as per recommendation. Water level of $5 \mathrm{~cm}$ was maintained after seven days of transplanting as per the irrigation treatments. Water requirement was calculated by adding effective rainfall during crop growth period, irrigation applied and profile contribution. Water use-efficiency was calculated from ratio of grain yield to the water requirement for each treatment. The observations on yield attributes and yield were recorded.

The growing degree days (GDD) were computed from the date of sowing onwards till physiological maturity by considering the base temperature $(\mathrm{Tb})$ of the crop as $10^{\circ} \mathrm{C}$ using the following formula:

Accumulated GDD $\left({ }^{\circ} \mathrm{C}\right.$ day $)=$

Where,Tmean is daily mean $\sum$ Tmean $\left.-\mathrm{Tb}\right)=(\operatorname{Tmax}$ $+\mathrm{Tmin}) / 2$

Heat use efficiency (HUE) was also computed as Grain yield heat use efficiency $($ GY-HUE $)=$ Grain yield $/$ GDD Dry matter heat use efficiency $($ DM-HUE $)=$ Dry matter/GDD

The recorded data for various parameters were statistically analyzed using standard procedures (Gomez and Gomez, 1984).

\section{RESULTS AND DISCUSSIONS}

\section{Growth parameters}

The poled data (Table1) indicated that irrigation schedule has significant effect on dry matter accumulation at harvest and leaf area index at 50 per cent flowering but plant height and maximum days taken to 50 per cent flowering were not affected significantly. Dry matter accumulation at harvest and leaf area index at 50 per cent flowering with 
Table 2: Heat utilization, water use efficiency and economics of summer transplanted rice in relation to irrigation schedules and date of transplanting (pooled data of 3 years - 2011 to 2013).

\begin{tabular}{|c|c|c|c|c|}
\hline Treatments & $\begin{array}{l}\text { Water requirement } \\
\qquad(\mathrm{cm})\end{array}$ & $\begin{array}{c}\text { Field water use } \\
\text { efficiency } \\
\left(\mathrm{kgha}^{-1} \mathrm{~cm}^{-1}\right)\end{array}$ & $\begin{array}{c}\text { Dry matter heat } \\
\text { use efficiency } \\
(\mathrm{DM}-\mathrm{HUE}) \\
\left(\mathrm{kg} \mathrm{ha}^{-10} \mathrm{C}^{-1} \mathrm{day}^{-1}\right)\end{array}$ & $\begin{array}{l}\text { Grain yield heat } \\
\text { use efficiency } \\
(\text { GY-HUE }) \\
\left(\mathrm{kg} \mathrm{ha}^{-10} \mathrm{C}^{-1} \text { day }^{-1}\right)\end{array}$ \\
\hline \multicolumn{5}{|c|}{ Irrigation schedules } \\
\hline 1day after DPW & 83.7 & 36.7 & 3.62 & 1.84 \\
\hline 3days after DPW & 61.6 & 43.7 & 2.79 & 1.62 \\
\hline $\mathrm{SEm} \pm$ & - & 0.7 & 0.08 & 0.04 \\
\hline $\mathrm{CD}(\mathrm{P}=0.05)$ & - & 2.18 & 0.26 & 0.13 \\
\hline \multicolumn{5}{|c|}{ Date of transplanting } \\
\hline $15^{\text {th }}$ February & 72.6 & 36.7 & 2.67 & 1.43 \\
\hline $\mathrm{SEm} \pm$ & - & 0.32 & 0.12 & 0.04 \\
\hline $\mathrm{CD}(\mathrm{P}=0.05)$ & - & 0.91 & 0.33 & 0.10 \\
\hline
\end{tabular}

irrigation schedule at 1day after DPW was at par with irrigation schedule at 2-days after DPW and significantly higher compared to irrigation schedule at 3-days after DPW. Similarly, the date of transplanting exerted significant effect on plant height, dry matter accumulation at harvest, leaf area index at 50 per cent flowering and maximum days taken to 50 per cent flowering. Highest values of all the growth parameters were recorded when rice was transplanted on $15^{\text {th }}$ January. Plant height and dry matter accumulation of $15^{\text {th }}$ January transplanted rice was at par with those transplanted on $30^{\text {th }}$ January and significantly superior to transplanted on $15^{\text {th }}$ February. Whereas leaf area index at 50 per cent flowering and maximum days taken to 50 per cent flowering were significantly higher in rice transplanted on $15^{\text {th }}$ January compared to other dates.

\section{Yield attributes and yield}

Irrigation schedules had non-significant effect on effective panicles $\mathrm{m}^{-2}$ and filled grains panicle ${ }^{-1}$ whereas significant effect on test weight and grain yield (Table 1). The maximum value of effective panicles $\mathrm{m}^{-2}$, filled grains panicle $^{-1}$ and test weight was obtained with irrigation schedule at 1-day after DPW. However, the test weight of irrigation schedule at 1-day after DPW was at par with irrigation schedule at 2-days after DPW and significantly superior to irrigation schedule at 3-days after DPW. Grain yield $\left(3.07 \mathrm{t} \mathrm{ha}^{-1}\right)$ was recorded maximum with irrigation scheduled at 1-day after DPW and was at par with irrigation schedules at 2-day after $\operatorname{DPW}\left(2.96 \mathrm{t} \mathrm{ha}^{-1}\right)$ but it was significantly superior to irrigation scheduled at 3-days after DPW. Lower grain yield at irrigation scheduled at 3-days after DPW was probably due to imposed stress because of unavailability of sufficient moisture in the root zone which caused the shallow root to spend more energy to extract unit amount of nutrient and to meet the evaporative demand during summer season resulting in decreased number of yield attributes, increased unfilled grain percentage and reduced test weight. These results are in agreement with the findings of Ramkrishna et al. (2007) and Pandey et al. (2010).

The pooled data (Table1) indicated that date of transplanting exerted significant effect on effective panicles $\mathrm{m}^{-2}$, filled grains panicle ${ }^{-1}$, grain yield but test weight was not affected significantly. Maximum number of effective panicles $\mathrm{m}^{-2}$ and filled grains panicle ${ }^{-1}$ were produced when rice was transplanted on $15^{\text {th }}$ January and was at par with transplanted on $30^{\text {th }}$ January and significantly superior to transplanted on $15^{\text {th }}$ February. The highest grain yield $\left(3.11\right.$ tha $\left.^{-1}\right)$ was obtained transplanting on $15^{\text {th }}$ January which was significantly superior to observations under other transplanting dates of $30^{\text {th }}$ January and $15^{\text {th }}$ February. The lowest grain yield was produced with late transplanting because of crop shifts form vegetative into reproductive 
growth phase when entered into specific day length ultimately reduced their growth duration and poor yield. These are in line with findings of Muthukrishnan et al. (2000) and Khalid et al.(2006).

\section{Water use efficiency}

Water requirement and field water use efficiency for different irrigation schedules and date of transplanting are presented in Table 2. Highest water requirement of $83.7 \mathrm{~cm}$ was observed with irrigation schedule at 1-day after DPW whereas lowest value of $61.6 \mathrm{~cm}$ was observed with schedule irrigation schedule at 3-days after DPW. The treatment that received irrigation schedule at 3 -days after DPW registered a highest field water use efficiency of $43.7 \mathrm{~kg}$ ha- $\mathrm{cm}^{-1}$ which was significantly superior to irrigation schedule at 2-days after DPW and 1-day after DPW. The irrigation regimes at 1day after DPW gave lower water use efficiency though grain yield was higher but used in more quantity of water. The water requirement for different transplanting date treated plot which was the mean values of different irrigation treatment reflects the same value for all the transplanting date treated plots. The transplanting on $15^{\text {th }}$ January produced a highest field water use efficiency of $43.2 \mathrm{~kg}$ ha$\mathrm{cm}^{-1}$ which was significantly superior to other transplanting date on $30^{\text {th }}$ January and $15^{\text {th }}$ February. The higher field water use efficiency might in early transplanting i.e $15^{\text {th }}$ Januarybe due to increase in grain yield with almost constant rate of applied water.

\section{Heat use efficiency}

The treatment that received irrigation schedule at 1day after DPW registered the highest dry matter and grain yield heat use efficiency. Which was significantly superior to irrigation schedule at 2-days after DPW and 3-days after DPW with respect to dry matter heat use efficiency, whereas in case ofgrain yield heat use efficiency, it was at par withirrigation schedule at 2-days after DPW and significantly superior to 3 -days after DPW. The transplanting on $15^{\text {th }}$ January produced the highest dry matter and grain yield heat use efficiency which was significantly superior to other transplanting date i.e. $30^{\text {th }}$ January and $15^{\text {th }}$ February (Table 2).

\section{CONCLUSION}

These findings lead us to the conclusion that transplanting dates of a rice should be adjusted such that its reproductive growth phase dose not coincide with high temperature stress as it results in lower number of grains per panicle and lower grain weight resulting in lower grain yield. Rice variety Khandagiri produced economicallyhigher grain yield, water use efficiency and dry matter as well as heat use efficiency with transplanting date on $15^{\text {th }}$ January by the application of irrigation schedule at 2-days after DPW.

\section{REFERENCES}

Aggarwal,N.,Singh,A.,Singh,S.P. and Kang.J.S. (2015).Heat utilization vis-à-vis crop performance of mechanically transplanted rice as affected by tillage systems and nitrogen levels. J.Agrometeorol., 17(1): 84-89.

Gomez, K.A. and Gomez,A.A.(1984).Statistical procedures for agricultural research, $2^{\text {nd }}$ Edition. John Wiley \& Sons. pp: $357-423$.

Hassan, G., Khan, N.U. and Khan, Q.N. (2003).Effect of transplanting date on the yield and yield components of different rice cultivars under high temperature.Sci. Khy.,16(2): 129-137.

Khalid, M.M.R., Anwar,M.P., Kamal,M.M. and Rahman,M.S.(2006).Production potential of boridhan 28 as affected by transplanting date and nitrogen nutrition.PG thesis submitted to Bangladesh Agric. Univ., Mymensingh

Muthukrishnan, P., Ponnuswamy, K., Santhis, P. and Subramanian, M. (2000).Effect of transplanting time on the performance of rice hybrids in cauverydeltazone.Madras Agrilc. J.,87: 506-507.

Pandey, N.,Verma, A. K. and Tripathi.(2010). Response of hybrid rice to scheduling of nitrogen and irrigation during dry season.Oryza., 47:34-37.

Ramkrishna, Y., Singh, S. and Parihar, S.S. (2007).Influence of irrigation regimes and nitrogen management on productivity, nitrogen uptake and water use by rice. Indian J. Agron., 52:102-106.

Thiyagarajan, T.M., Selvaraju, R. (2001). Water saving in rice cultivation in India.Proceedings of an International Workshop on Water Saving Rice Production Systems. April 2-4, 2001.Nanjing University, China, pp.15-45. 